${ }^{1}$ General hospital Doboj

${ }^{2}$ Health center «ORS Hospital» Belgrade

${ }^{3}$ Center for Burns, Plastic and Reconstructive Surgery, Belgrade

${ }^{4}$ FZORS Banja Luka

${ }^{5}$ General hospital Prijedor

\title{
INFLUENCE OF RADICALITY SURGICAL EXCISION ON RESULTS IN THE TREATMENT OF BASOCELLULAR SKIN CARCINOMA (BCC)
}

\section{UTICAJ RADIKALNOSTI HIRURŠKE EKSCIZIJE NA REZULTATE LEČENJA BAZOCELULARNOG KARCINOMA KOŽE (BCC)}

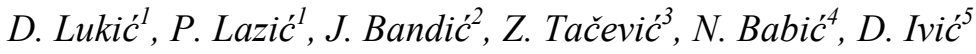

\section{Summary}

With the prospective study, from June 2003 to January 2013, were compared the results of treatment of basocellular carcinomas (BCC) of the skin in 210 respondents. The respondents were divided into 3 groups. The first group, group A (61 respondents) consisted of respondents treated for BCC with surgical excision, with distance incision of $1 \mathrm{~cm}$ from the tumor. In the second group, group B (79 respondents) were classified respondents treated for BCC with surgical excision, at distance incision $2 \mathrm{~cm}$ from the tumor, while the third group, group C (70 respondents) was classified by respondents treated with surgical excision of $B C C$, at distance incision approximately $3 \mathrm{~cm}$ from the tumor.

The parameters for comparison of treatment results were: the method (radicality) of treatment, number of the relapse, elapsed time from surgery to relapse and subsequent disfiguration.

The aim of this study was to determine the optimal radicality in the treatment of $B C C$, i.e., the number of relapses in relation to the radicalism of the $B C C$ excisions.

In most of the respondents, intraoperative skin defect was closed by direct suture. Spare distance, from the edge of the BCC, which amounts to $1 \mathrm{~cm}$ in group $A$, results in significantly lower percentage of disfigurement. At the same time, in group $A$ was recorded the highest number of recurrences of $B C C$.

Radical surgeries of $B C C$, which were performed with the resection margin of $3 \mathrm{~cm}$ from the $B C C$, resulted in the lowest number of relapses, but statistically significant percentage of postoperative disfigurement. The most optimal excisional distance from the edge of the $B C C$ is about $2 \mathrm{~cm}$. Due to the significantly smaller number of disfigurement, resections distance of $2 \mathrm{~cm}$ from the BCC and direct suture of postoperative defect take precedence, regardless of the localization of the tumor.

Key words: skin, tumors, treatment

\section{Sažetak}

Prospektivnom studijom, $u$ periodu od juna 2003. januara 2013. godine, upoređivani su rezultati liječenja bazocelularnog karcinoma (BCC) kože kod 210 ispitanika. Ispitanici su podijeljeni u 3 grupe. Prvu, grupu A (61 ispitanika), činili su ispitanici liječeni od BCC hirurškom ekscizijom sa distancom incizije od tumora od $1 \mathrm{~cm}$. U drugu, grupu B (79 ispitanika), svrstani su ispitanici liječeni od BCC hirurškom ekscizijom sa distancom incizije od tumora 2 cm., dok su u treću, grupu C (70 ispitanika), svrstani ispitanici liječeni od BCC hirurškom ekscizijom, sa distancom incizije od tumora prosječno $3 \mathrm{~cm}$.

Parametri za poređenje rezultata liječenja bili su: metod (radikalnost) liječenja, broj recidiva, vrijeme proteklo od operacije do recidiva $i$ posljedično unakaženje.

Cilj rada bio je da se utvrdi, optimalna radikalnost u liječenju $B C C$, odnosno, broj recidiva $u$ odnosu na radikalnost pri ekscizijama BCC.

Kod najvećeg broja ispitanika, intraoperativni defekt kože zatvoren je direktnom suturom. Poštedna distanca od ruba BCC koja iznosi $1 \mathrm{~cm}$ u grupi $A$, rezultuje statistički značajno manjim procentom unakaženja. Istovremeno, u grupi A zabilježen je najveći broj recidiva $B C C$.

Radikalne operacije BCC koje su ivedene sa resekcionom ivicom od $3 \mathrm{~cm}$ od $B C C$ rezultovale su najmanjim brojem recidiva ali $i$ statistički značajnim procentom postoperativnog unakaženja.

Najoptimalnija eksciziona distanca od ruba BCC je oko $2 \mathrm{~cm}$. Zbog statistički značajno manjeg broja unakaženja, resekciona distanca $2 \mathrm{~cm}$ od $B C C i$ 
direktna sutura postoperativnog defkta imaju prednost, bez obzira na lokalizaciju tumora.

Ključne riječi: koža, tumori,liječenje

\section{Introduction}

Basocellular carcinoma (BCC) is the most common cause of postoperative disfigurement on the face in people who had not promptly identified and removed this malignant disease. 1 This type of skin cancer usually appears as a harmless erosion of the epidermis, accompanied by a slight arborization of blood vessels and discrete ulcers that bleed occasionally. Crust that covers the focus of BCC occasionally falls off and makes a new form, giving a harmless appearance of lesion for a long time. 2

Frequent bleedings are the most common reason of sending the patient to the dermatologist. Dermatologic examination that involves Dermascopy will precisely confirm that it is BCC. 3

When $\mathrm{BCC}$ is diagnosed in time, it requires less sufficient surgical excision, which will usually lead to cure. Any post excisional defect of minor BCC lesion, can be reconstructed by direct suture and usually without disfigurement. 1-3 This is particularly important when the $\mathrm{BCC}$ is positioned on the face of the patient.

On the contrary, when locally advanced BCC is neglected, radical excision is required, which inevitably leads to a certain degree of disfigurement.

Regardless of the extent of the lesion, there is the question of optimal radicality of surgical excision of BCC. Ideal radicalism would be the one that eradicates the tumor without any traces, which might disfigure the patient in any percentage. 4

As there is no perfect solution, the optimal radicalism implies the distance of excisional cut of $\mathrm{BCC}$, which will mean local sterilization and prevent the growth/recurrence of BCC. At the same time, it is necessary to choose the method for the reconstruction post excisional defect that will cause less damage to the patient's appearance, considering the size of previously removed lesions. 5

There is no universal formula for both these problems. Rather, the scope of radicalism and reconstruction of the postoperative defect are in the zone of surgeon's estimate that must have measure, knowledge and resolve to do the best for his patient.

\section{Goal}

The aim of this study was to determine the optimal radicalism in the treatment of BCC, i.e., the number of relapses in relation to the radicalism of the BCC excisions. At the same time, the aim of this study was the analysis of the frequency of disfigurement as the consequence of the surgical treatment of BCC.

\section{Respondents and methods}

A prospective clinical study, which lasted from June 2003 to January 2013, included respondents treated for BCC of the skin. Respondents were divided into 3 groups.

The first group, group A (61 respondents) consisted of respondents treated for BCC with surgical excision with distance incision of $1 \mathrm{~cm}$ from the tumor. In the second group, group B (79 respondents) were classified respondents treated for BCC with surgical excision, distance incision of $2 \mathrm{~cm}$ from the tumor, while the third group, group C (70 respondents) was classified by respondents treated for BCC with surgical excision, distance of incision approximately $3 \mathrm{~cm}$ from the tumor. For diagnosis were used: medical history, clinical examination and computerized dermoscopy, and after excision the definitive pathohistological analysis.

Tables 1, 2 and 3 show the distribution of respondents by gender, age and anatomic position of the BCC whereas Table 4 shows clinical finding of $\mathrm{BCC}$, or the degree of lesions progression.

\section{Table 1. Respondents by gender}

\begin{tabular}{|l|l|l|l|}
\hline Gender & Group A & Group B & Group C \\
\hline Male & $34(55.7 \%)$ & $43(\%)$ & $38(54.3)$ \\
\hline Female & $27(44.3 \%)$ & $36(\%) 22$ & $32(45.7 \%)$ \\
\hline Total & $61(100 \%)$ & $79(100 \%)$ & $70(100 \%)$ \\
\hline
\end{tabular}

Table 2. Respondents by age

\begin{tabular}{|l|l|l|l|}
\hline Age & Group A & Group B & Group C \\
\hline $20-30$ & $2(3.3 \%)$ & $1(1.2 \%)$ & $4(5.7 \%)$ \\
\hline $30-40$ & $3(4.9 \%)$ & $1(1.2 \%)$ & $3(4.2 \%)$ \\
\hline $40-50$ & $11(18.1 \%)$ & $16(20.3 \%)$ & $12(17.2 \%)$ \\
\hline $50-60$ & $18(29.5 \%)$ & $26(32.9 \%)$ & $18(25.8 \%)$ \\
\hline $\begin{array}{l}\text { Over } \\
60\end{array}$ & $27(44.2 \%)$ & $35(44.4 \%)$ & $33(47.1 \%)$ \\
\hline Total & $61(100 \%)$ & $79(100 \%)$ & $70(100 \%)$ \\
\hline
\end{tabular}

Table 3. The distribution of respondents according to anatomic position of the $B C C$

\begin{tabular}{|l|l|l|l|}
\hline Position & Group A & Group B & Group C \\
\hline Head & $35(57.3 \%)$ & $33(41.8 \%)$ & $41(\%)$ \\
\hline Neck & $5(8.3 \%)$ & $4(5.1 \%)$ & $6(\%)$ \\
\hline $\begin{array}{l}\text { Chest and } \\
\text { abdomen }\end{array}$ & $13(21.4 \%)$ & $19(24.1 \%)$ & $5(\%)$ \\
\hline Back & $4(6.6 \%)$ & $15(18.9 \%)$ & $6(\%)$ \\
\hline $\begin{array}{l}\text { Upper } \\
\text { extremities }\end{array}$ & $2(3.2 \%)$ & $6(7.5 \%)$ & $5(\%)$ \\
\hline $\begin{array}{l}\text { Lower } \\
\text { extremities }\end{array}$ & $2(3.2 \%)$ & $2(2.6 \%)$ & $7(\%)$ \\
\hline Total & $61(100 \%)$ & $79(100 \%)$ & $70(100 \%)$ \\
\hline
\end{tabular}


Table 4. Local finding

\begin{tabular}{|l|l|l|l|}
\hline $\begin{array}{l}\text { Condition of } \\
\text { lesion }\end{array}$ & Group A & Group B & Group C \\
\hline $\begin{array}{l}\text { Small, } \\
\text { limited } \\
\text { lesion }\end{array}$ & $51(83.6 \%)$ & $58(73.5 \%)$ & $40(57.2 \%)$ \\
\hline $\begin{array}{l}\text { Progressed } \\
\text { lesion }\end{array}$ & $10(16.3 \%)$ & $21(26.5 \%)$ & $30(42.8 \%)$ \\
\hline Total & $61(100 \%)$ & $79(100 \%)$ & $70(100 \%)$ \\
\hline
\end{tabular}

\section{Results}

Results of the treatment of BCC in the investigated groups are shown in Tables 4-7 and Figure 1- 2. Parameters for comparison were: the method of reconstruction on post excision defect, number of relapses, the time elapsed from excision of tumor to relapse and postoperative disfigurement.

Table 4. Result- the method of reconstruction post excision defect

\begin{tabular}{|l|l|l|l|}
\hline Method & Group A & Group B & Group C \\
\hline $\begin{array}{l}\text { Direct } \\
\text { suture }\end{array}$ & $51(83.7 \%)$ & $63(79.7 \%)$ & $13(18.6 \%)$ \\
\hline $\begin{array}{l}\text { Skin } \\
\text { transplant }\end{array}$ & $0(0 \%)$ & $0(\%)$ & $30(42.8 \%)$ \\
\hline Flap & $10(16.3 \%)$ & $16(20.3 \%)$ & $27(38.6 \%)$ \\
\hline Total & $61(100 \%)$ & $79(100 \%)$ & $70(100 \%)$ \\
\hline
\end{tabular}

Table 5. Result-relapse

\begin{tabular}{|l|l|l|l|}
\hline $\begin{array}{l}\text { Relaps } \\
\text { e }\end{array}$ & $\begin{array}{l}\text { Group } \\
\text { A }\end{array}$ & $\begin{array}{l}\text { Group } \\
\text { B }\end{array}$ & $\begin{array}{l}\text { Group } \\
\text { C }\end{array}$ \\
\hline Yes & $\begin{array}{l}14(22.9 \\
\text { \%) }\end{array}$ & $\begin{array}{l}6(7.6 \% \\
)\end{array}$ & $\begin{array}{l}6(8.5 \% \\
)\end{array}$ \\
\hline No & $\begin{array}{l}47(77.1 \\
\text { \%) }\end{array}$ & $\begin{array}{l}73(92.4 \\
\text { \%) }\end{array}$ & $\begin{array}{l}64(91.5 \\
\text { \%) }\end{array}$ \\
\hline Total & $\begin{array}{l}61(100 \\
\text { \%) }\end{array}$ & $\begin{array}{l}79(100 \\
\text { \%) }\end{array}$ & $\begin{array}{l}70(100 \\
\text { \%) }\end{array}$ \\
\hline
\end{tabular}

Figure 1. Result-relapse

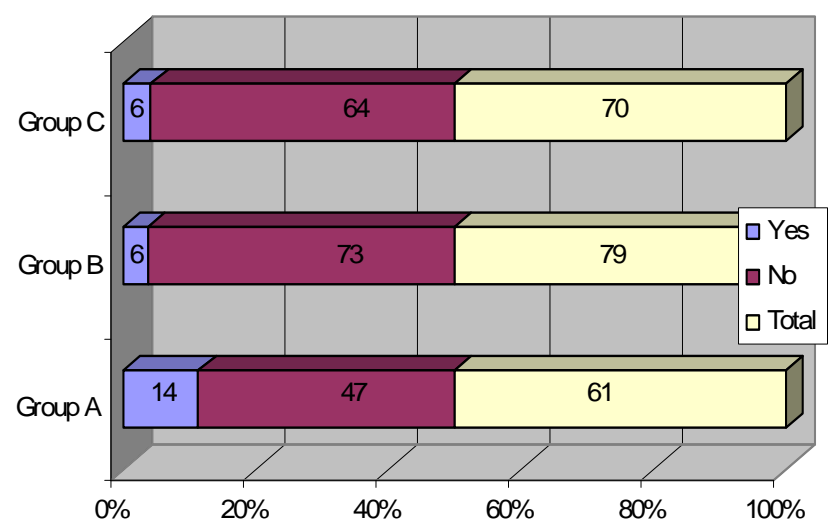

Table 6. Result-time from surgery until relapse

\begin{tabular}{|l|l|l|l|}
\hline $\begin{array}{l}\text { Time } \\
\text { (months) }\end{array}$ & $\begin{array}{l}\text { Group } \\
\text { A }\end{array}$ & $\begin{array}{l}\text { Group } \\
\text { B }\end{array}$ & $\begin{array}{l}\text { Group } \\
\text { C }\end{array}$ \\
\hline & $16 \times 2$ & 14 & 11 \\
\hline & $24 \times 2$ & 22 & 14 \\
\hline & $27 \times 2$ & 26 & 23 \\
\hline & $33 \times 3$ & 22 & 26 \\
\hline & $35 \times 3$ & 26 & 33 \\
\hline & $40 \times 2$ & 40 & 36 \\
\hline Total & 14 & 6 & 6 \\
\hline
\end{tabular}

Table 7. Result - postoperative disfigurement

\begin{tabular}{|l|l|l|l|}
\hline Disfigurement & Group A & Group B & Group C \\
\hline Yes & $8(13.2 \%)$ & $7(8,8 \%)$ & $40(\%)$ \\
\hline No & $53(86.8 \%)$ & $72(\%)$ & $30(\%)$ \\
\hline Total & $61(100 \%)$ & $79(100 \%)$ & $70(100 \%)$ \\
\hline
\end{tabular}

Figure 2. Result - postoperative disfigurement

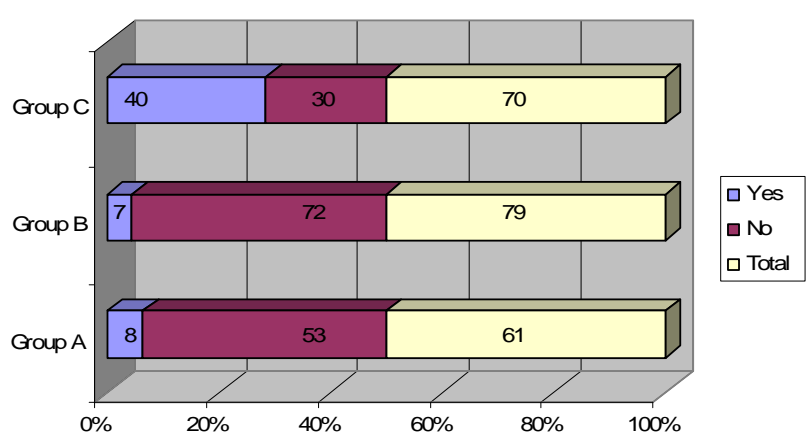

Statistical analysis determined the difference between individual groups of respondents in the following characteristics:

- Between groups $\mathrm{A}$ and $\mathrm{C}$ in terms of the characteristics of the method of reconstruction post excision defect $(\mathrm{p}<0.01,99 \%$ confidence $), Z=$ 2.33542

- Between groups $\mathrm{B}$ and $\mathrm{C}$ in terms of the characteristics of the method of reconstruction post excision defect ( $p<0.01,99 \%$ confidence), $Z=$ 3.99274

- Between groups $\mathrm{A}$ and $\mathrm{B}$ in terms of the characteristics of relapse ( $p<0.05$ - not highly significant)

- Between groups $\mathrm{A}$ and $\mathrm{C}$ in terms of the characteristics of relapse $(p<0.05$ - not highly significant)

- Between groups $\mathrm{A}$ and $\mathrm{C}$ in terms of the characteristics of postoperatively disfigurement ( $p$ $<0.01,99 \%$ confidence), $\mathrm{Z}=3.6926$

- Between groups $\mathrm{B}$ and $\mathrm{C}$ in terms of the characteristics of postoperatively disfigurement $(p$ $<0.01,99 \%$ confidence), $\mathrm{Z}=2.1023$ 


\section{Discussion}

Basocellular carcinoma (BCC) of the skin is the most common non-melanoma cancer. For the BCC is true that it more often occurs in males and older age, but recent analyses show increasing incidence of skin cancer among younger people. They can also be seen in children. 6

Of our 210 respondents with skin cancer, 95(45, $3 \%)$ were female and $115(34,7 \%)$ male. The youngest respondent was 22 years old and the oldest 75 years.

$\mathrm{BCC}$ begins as a small, waxy node, which often shows several small telangiectasias (chronic dilated blood vessels on the surface of the skin). A node typically increases slowly and often goes through a specific ulceration. The typical lesion is then made by successive ulcer enlargement surrounded by pearly curved edge. 7

Our research has shown that the majority of patients underwent surgery at the stage of tumor development that can be characterized as "small, well circumscribed lesion". By this characteristic, there were no statistical differences between groups A, B and $\mathrm{C}$.

Basocellular carcinomas usually appear as single lesions, but can often appear more foci of BCC, and at the same time or one after the. Bleeding from the tumor foci usually comes in the later stage of BCC development. This sporadic bleeding in nearly all respondents led to a visit to the doctor.

Most BCC have limited potential for growth, however, they may occasionally be infiltrative and aggressive and then reach a significant size and penetrate deeply. On the face, it can ruin the eyes and nose, or it can penetrate the skull and attack menix. In this form, this tumor can be fatal. 8

Quick diagnosis, especially of the initial lesion, is possible before surgery by applying computer (digital) Dermoscopy. This diagnosis allows timely detection of the character of the lesion and radical removal of BCC, which reduces the risk of relapse and improves the prognosis of treatment.

A small number of our respondents had the tumor in locally advanced stage of BCC and without significant statistical difference between the observed groups. A number of locally advanced BCC in our respondents, was recorded on the scalp (within group $\mathrm{C}$ ), probably due to the position of the $\mathrm{BCC}$. In one patient in group $\mathrm{C}$, the tumor was in an extreme phase when scalp and Calvary were destroyed, with the lesion invasion in meninx.

The basic postulate of plastic and reconstructive surgery is the removal of the tumor with optimal radicalism, and that the operating defects are closed by simplest method. 1,6 It is primarily important enough to radically remove tumor.9 Direct suture is the best solution whenever it is possible to apply. 9 However, direct suture is often not possible, so it is necessary to use cutaneous transplant or some of cutaneous flaps. 10 We closed most of excisional defects in our respondents in group A by direct suture, because the distance of the excision line from the edge of the tumor $(1 \mathrm{~cm})$ allowed this type of suturing of the skin without significant tension and disfigurement.

Most of skin transplantations were done in group C. The reason for this is the increasing number of advanced lesions in this group and wider excision distance from the edge of the tumor $(3 \mathrm{~cm})$, which resulted in postoperative defects.

About $40 \%$ of patients with basocellular carcinoma will have one or more basocellular carcinoma within 10 years. 11

$\mathrm{BCC}$ of the skin of the nose more often recur than at other areas on the head and face. It seems that the reason is avoiding radical incision during the surgery. 12 There have been persistent recurrences of BCC on scalp, despite the radical excisions. 12

Various studies have determined the certain parameters and risk factors that lead to relapse and progression of disease. These are macroscopic parameters (size, shape and multiplicity of tumors) and microscopic parameters (the degree of cell differentiation). 11

In group A were found 14 relapses of skin BCC. Relapse occurred in 6 patients in group B while in group $\mathrm{C}$ the number of relapses was also six. The average time from tumor excision to recurrence did not differ from the date from the literature and was on average 24.7 months.

Frequent recurrences of $\mathrm{BCC}$ in group A were especially recorded after excisions of the face. This can be explained by attempting to avoid the radicalism that leads to disfigurement. In contrast, in group $\mathrm{C}$, where there were the highest number of respondents with locally advanced lesions and the highest radicalism of excision, there was proportionally lower number of relapses. The greatest radicalism had been applied to treat tumors that were higher locally and in advanced phase.

Rarer are BCC surgeries on the head, which does not leave traces behind.2 On the contrary, the more radical surgery for operations BCC on the head usually causes a certain degree of disfigurement. 6-9 When it comes to treatment and removal of BCC from head skin, aesthetics is a second plan, but still taken into account that the optimal excision are not left behind degree of disfigurement, which will later present mental burden for the patient. 10

BCC surgery on the nose, especially at the advanced stage, will usually lead to the obvious scar, which is seen as a certain degree of disfigurement. Direct suture zone on the nose often leads to displacement of tissue, so it is more or less damaging pre-existing architecture of the nose. Local rotational 
or transpositional flaps often leave traces, by which it can be known that the nose has been operated. 3

Direct suture is probably the most applicable option for BCC surgeries on the face, because usually there is enough skin, which can cover an operating defect directly. The possibility of closing surgical defect after excision of BCC on the scalp is very limited already for the defects of $1.5 \mathrm{~cm}$ in diameter. 3 In advanced $\mathrm{BCC}$ on scalp, direct suture is practically out of the question. Cutaneous transplantation, the thickness of the skin ruptured is the most common surgical method of closing post excision defect in the treatment of BCC scalp. This method, however, leaves behind sharply demarcated areas without hair, and if it is impossible to disguise them surrounding hair there are visible disfigurements, which attract attention. 3,4 In our respondents, in group $\mathrm{C}$, in most cases there is a certain degree of disfigurement, as a consequence of the reconstruction of post excision defect by skin graft. Areas that appeared smooth and without hair, were more or less conspicuous and are characterized as disfigurement, which is the cost of treatment for specifically advanced BCC.

Disfigurements in respondents in groups A and $\mathrm{B}$, therefore, on the nose and other facial parts, mostly consisted of visible scars from surgery. Scar size and degree of such disfigurement, is directly proportional to the size of the tumor that was removed.

There is a belief that basocellular carcinoma $(\mathrm{BCC})$, generally do not metastasize, however, there are exceptions.6

Depending on the source of data in literature, the occurrence of metastasis varies from $0.01 \%$ (according to the pathologist reports), to $0.028 \%$ (according to the reports dermatologists) to $0.1 \%$ (according to data from surgical centers). A report published in 1984, described 175 cases with histopathological proven BCC metastases. 3-5

Typical history of basocellular carcinoma (BCC) with metastases is usually associated to large, ulcer, locally Invasive and destructive primary lesion, which appeared again in spite of repeated surgical interventions or radiotherapy.7-10

However, massive size, ulceration, or occurrence of multiple relapses is not absolute prerequisites for metastasis. Most researches have not established a specific histologic type of $\mathrm{BCC}$ that is more prone to metastasis than others. Also, there is no evidence that the immune defense of the host was significantly affected. However, some authors argue that metatypical or (basosquamous) basocellular type of cancer is most likely to metastases.

Unlike metastatic squamous cell carcinoma of the skin (PCC), which show limphogenously metastases in $80 \%$ to $90 \%$ of cases, the metastatic BCC, hematogenous and lymphatic spread shows almost uniform distribution. $4,8,11$

Thus, about $50 \%$ of patients with metastatic BCC develop metastases into the lymph nodes. Meanwhile, in the first line of the spread of haematogenic BCC are the lungs and bones. There was the appearance of metastases in the liver and other abdominal organs as well as skin or subcutaneous tissue. $4,8,12$

The average duration of life after metastasis to the lungs, bones or other organs is about 10 months. $4,8,12,13,14$

During our research, we did not encounter a single case of metastases of BCC.

\section{Conclusion}

In most of the respondents, intraoperative skin defect was closed by direct suture. Sparing incision distance from the edge of the BCC, which is $1 \mathrm{~cm}$ in group A, results in significantly lower percentage of disfigurement. Meanwhile in group A was recorded the highest number of relapses of BCC.

Radical surgeries of $\mathrm{BCC}$ that were undertake with surgical margin of $3 \mathrm{~cm}$ from the $\mathrm{BCC}$ resulted in fewer relapses, but statistically significant percentage of postoperative disfigurement.

The most optimal excisional distance from the edge of the $\mathrm{BCC}$ is about $2 \mathrm{~cm}$. Due to the significantly smaller number of disfigurement, resections distance of $2 \mathrm{~cm}$ from the BCC and direct suture of postoperative defect take precedence, regardless of the tumor localization.

Local adverse effect of treatment of BCC, the consequently disfigurement was significantly more frequent in respondents who had post excision defect closed by cutaneous graft.

\section{References}

1. Rogers H.W., Weinstock M.A., Harris A.R Incidence estimate of nonmelanoma skin cancer in the United States, (2006) Arch Dermatol,2010; 283:287.

2. Oprić M., Babić M., Granić V. Tumori mekih tkiva i kože, Elit Medica, Beograd, 1999.

3. Lukić D. Tumori kože, Medicinski fakultet Banja Luka, 2010;45-48.

4. Lukić D., Bandić J., Ivić D. Rezultati lečenja planocelularnog i bazocelularnog kercinoma kože glave i vrata $i$ drugih anatomskih regija, Medicinska istraživanja, 2006;40(1): 29-35.

5. Anwar U., Ghazal A.S.K., Ahmad M., Sharpe D.T. Horrifying basal cell carcinoma forearm lesion leading to shoulder disarticulation. Plast Reconstr Surg, 2006; 117-9 
6. Asilian A., Tamizifar B. Aggressive and neglected basal cell carcinoma. Dermatologic Surgery, 2005;31(11):1468-1471

7. Braun-Falco O., Plewig G., Wolff H.H., Winkeimann R.K. Malignant epithelial tumors. in: Braun Falco O., Plewig G.Wolff H.H., Winkeimann R.K. (ur.) Dermatology, Berlin: Springer-Verlag, 1991;1018-35

8. Deo S.V., Hazarika S., Shukla N.K., Kumar S., Kar M., Samaiya A. Surgical management of skin cancers. Experience from a regional cancer centre in North India. Indian journal of cancer, 2005;42(3) 145-50.

9. Eisner J.M., Russell M. Cartilage hair hypoplasia and multiple basal cell carcinomas. J Am Acad Dermatol, 2006;54-8

10. Hutcheson A.C., Fisher A.H., Lang P.G. Basal cell carcinomas with unusual histologic patterns. Journal of the American Academy of Dermatology, 2005;53(5): 833
11. McCutcheon B., White K., Kotwall C., Germolic D., Rebolloso Y., Hamann M.S., Stiles A. A preliminary study of imiquimod treatment in variants of basal cell carcinoma. Am Surg, 2005;71(8): 662-5

12. Pennington B.E., Leffe D.J. Mohs micrographic surgery. Established uses and emerging trends. Oncology, Willston Park, Aug. 2005;19(9):116571

13. Rončević R., Aleksić V., Stojičić M., Jovanović M., Rončević D. Invasive, aggresive basal cell carcinoma. Carcinoma basocellulare terebrans. European Journal of Plastic Surgery, 2006;(23): 379-384

14. Padgett JK, Hendrix JD Jr. Cutaneous malignancies and their management. Otolaryngol Clin North Am, 2001;34:523-553

15. Lukić D., Karabeg R., Bandić J. The Results of Treatment of Basocellular Carcinomas of the Head Skin. Medical Archives, 2012;66(3):72-78. 